\title{
ТРОМБОПРОФІЛАКТИКА ПРИ РЕВАСКУЛЯРИЗУЮЧИХ ОПЕРАЦІЯХ У ПАЦІЄНТІВ ІЗ АТЕРОСКЛЕРОТИЧНИМ УРАЖЕННЯМ МАГІСТРАЛЬНИХ АРТЕРІЙ НИЖНІХ КІНЦІВОК ЗА УМОВИ ХРОНІЧНОÏ КРИТИЧНОÏ ІШЕМІї
}

\author{
๑О. Б. Колотило
}

\section{Вищий державний навчальний заклад україни «Буковинський державний медичний університет»}

РЕзюМЕ. Реконструктивні методи лікування дають можливість зберегти нижні кінцівки, за критичної ішемії їх тканин, у 45-55 \% хворих. Незважаючи на застосування різних хірургічних технологій у лікуванні облітеруючих захворювань аорти та периферійних артерій нижніх кінцівок, сьогодні досить значною є частота як ранніх, так і пізніх ускладнень реконструктивних втручань, зокрема, тромбоз сегмента реконструкції виявляють у 42-59 \%. спостережень. Тромбопрофілактика з використанням галузевих протоколів, застосування алопротезів 3 імпрегнацією іонів срібла не вирішують проблему.

Мета - дослідження системи гемостазу при реваскуляризуючих операціях у пацієнтів із атеросклеротичним ураженням магістральних артерій нижніх кінцівок за умови хронічної критичної ішемії та розробка відповідної тромбопрофілактики.

Матеріал і методи. Ообстежені 106 пацієнтів, з яких у 18 хворих діагностована аневризма інфраренальної частини аорти, у 39 - атеросклеротична оклюзія аорто-клубового сегмента, у 13 з них - сегментарна оклюзія стегново-дистального артеріального русла; у 12 - клубово-стегнова атеросклеротична оклюзія, у 27 - стенотичнооклюзійне атеросклеротичне ураження стегново-дистального артеріального русла нижніх кінцівок. В усіх пацієнтів при атеросклеротичному ураженні артеріальної системи нижніх кінцівок діагностована хронічна артеріальна ішемія IIIA - IIIB стадії (за А. В. Покровським).

Результати. Під час проведення реконструктивних операцій у пацієнтів із атеросклеротичним ураженням магістральних артерій нижніх кінцівок за умови хронічної критичної ішемії, спосіб тромбопрофілактики має передбачати внутрішньовенне введення нефракціонованого гепарину, який проявляє домінантну дію на Ila фактор (тромбін - фібриноген) гемокоагуляційного каскаду відразу після операційного втручання. Саме поєднання нефракціонованого гепарину (НФГ) і низькомолекулярного гепарину (НМГ) дає можливість одночасно впливати на різні чинники згортальної системи і знизити ризик розвитку тромбозу в судинній системі. Пацієнтам із високим ризиком розвитку реперфузійних ускладнень з метою тромбопрофілактики слід застосовувати лікувальні дози антикоагулянтних препаратів.

Висновок. У зв'язку із збереженням гіперкоагуляційного стану згортальної системи крові впродовж першої доби слід продовжувати призначення НФГ у половинній від початкової дози препарату протягом наступних 7-9 діб. 3 другої доби раннього післяопераційного періоду тромбопрофілактику НФГ можна замінити НМГ, які проявляють домінантну дію на Ха фактор гемокоагуляційного каскаду.

КлючовІ слОВА: тромбопрофілактика; хронічна критична ішемія; реперфузійний синдром; реваскуляризація.

Вступ. Хронічні облітеруючі захворювання аорти та артерій нижніх кінцівок становлять понад $20 \%$ у структурі серцево-судинних захворювань, тобто їх виявляють у 2-3 \% населення [1]. ̈̈х особливістю $\epsilon$ невпинно прогресуючий перебіг, що характеризується збільшенням вираженості переміжної кульгавості і переходом її в постійний больовий синдром або гангрену, що виявляють у 15-20 \% хворих [2]. Реконструктивні методи лікування дають можливість зберегти нижні кінцівки за критичної ішемії їх тканин у 45-55 \% хворих [3]. Незважаючи на застосування різних хірургічних технологій в лікуванні облітеруючих захворювань аорти та периферійних артерій нижніх кінцівок [4], сьогодні досить значною $\epsilon$ частота як ранніх, так і пізніх ускладнень реконструктивних втручань [5], зокрема, тромбоз сегмента реконструкції виявляють у 42-59 \% спостережень. Тромбопрофілактика з використанням галузевих прото- колів [6], застосування алопротезів з імпрегнацією іонів срібла не вирішують проблему [7].

Мета - дослідження системи гемостазу при реваскуляризаційних операціях у пацієнтів із атеросклеротичним ураженням магістральних артерій нижніх кінцівок за умови хронічної критичної ішемії та розробка відповідної тромбопрофілактики.

Матеріал і методи дослідження. Обстежені 106 пацієнтів, яких з приводу атеросклеротичного ураження аорти та магістральних артерій нижніх кінцівок лікували у відділенні судинної хірургії Тернопільської університетської лікарні. Всі пацієнти були прооперовані. У 18 хворих діагностована аневризма інфраренальної частини аорти, у 39 - атеросклеротична оклюзія аорто-клубового сегмента, у 13 з них - сегментарна оклюзія стегново-дистального артеріального русла; у 12 - клубово-стегнова атеросклеротична оклюзія, у 27 - 
Огляди літератури, оригінальні дослідження, погляд на проблему, випадок з практики, короткі повідомлення стенотично-оклюзійне атеросклеротичне ураження стегново-дистального артеріального русла нижніх кінцівок. В усіх пацієнтів при атеросклеротичному ураженні артеріальної системи нижніх кінцівок діагностована хронічна артеріальна ішемія IIIA - IIIB стадії (за А. В. Покровским). Визначали показники згортальної та фібринолітичної системи: вміст фібриногену - за ваговою методикою гравіметричним методом (за Р. А. Рутбергом); активність фібриностабілізувального фактора - 3 використанням набору для визначення фактора XIII науково-виробничої фірми «SIMKO Ltd» (Львів); тромбопластичну активність крові - за методом Б. А. Кудряшова, П. Д. Улитиной; час рекальцифікації плазми (ЧРП) - за методом Бергергоф і Рока; вміст плазміну (ПЛ), плазміногену (ПГ), сумарну фібринолітичну активність (СФА) - за методом В. А. Монастирської і співавт.; час лізису еуглобінових згустків (ЧЛЕЗ) - за допомогою набору для визначення фібринолітичної активності плазми крові науково-виробничої фірми "SIMKO Ltd» (Львів). Розчинні комплекси мономерів фібрину (РКМФ) вивчали планшетним методом; агрегаційні властивості тромбоцитів - під впливом АДФ в концентрації 2,5 мкмоль/л з записом агрегатограм на аналізаторі AP 2110 "Солар".

Результати й обговорення. Дослідженнями встановлено, що операційне втручання супроводжується посиленням гіперкоагуляційних та агрегаційних властивостей системи крові. Варто зазначити, що гіперкоагуляційна та агрегаційна системи крові у пацієнтів із високим ризиком розвитку реперфузійних ускладнень проявляє вищий ступінь активності, порівняно з пацієнтами із атеросклеротичним ураженням магістральних артерій нижніх кінцівок і XАН IIIA - IV ст.

Виявлено, що рівень показників згортальної системи поступово зростає впродовж операційного втручання, досягаючи максимальних значень через 3 год після нього. Подібне відбувається за рахунок зростання вмісту фібриногену в плазмі крові.

Одночасно відбувається суттєве підвищення рівня розчинних комплексів мономерів фібрину (РКМФ). Поява в крові підвищеного вмісту РКМФ свідчить про зростання рівня тромбінемії. Підтвердженням вказаного $є$ високий вміст у плазмі крові фібринопептиду А (ФПА) і одночасне посилення деградації продукту фібрину (ПДФ). Вказаному процесу сприяє зниження фібринолітичної активності крові (ФАК) та пришвидшення часу рекальцифікації плазми (ЧРП).

Отримані результати дослідження згортальної системи крові на інтраопераційному етапі хірургічного втручання свідчать про високий ризик розвитку тромботичного процесу в судинах, що

зумовлено низькою активністю фібринолітичної системи крові та підвищеним ступенем активності агрегаційної системи крові.

Стан гіперкоагуляції на інтраопераційному етапі хірургічного втручання формується за рахунок зростання вмісту в крові фібрин-тромбінової фракції гемокоагуляційного каскаду, яка сприяє формуванню фібриногену. Для впливу на вищезазначений процес слід призначати антикоагулянт, який має цілеспрямовану дію на Ila фактор коагуляційної системи.

Такі ж властивості має нефракціонований гепарин (НФГ). Дія НМГ переважно спрямована на Ха фактор гемокоагуляційного каскаду (рис. 1).

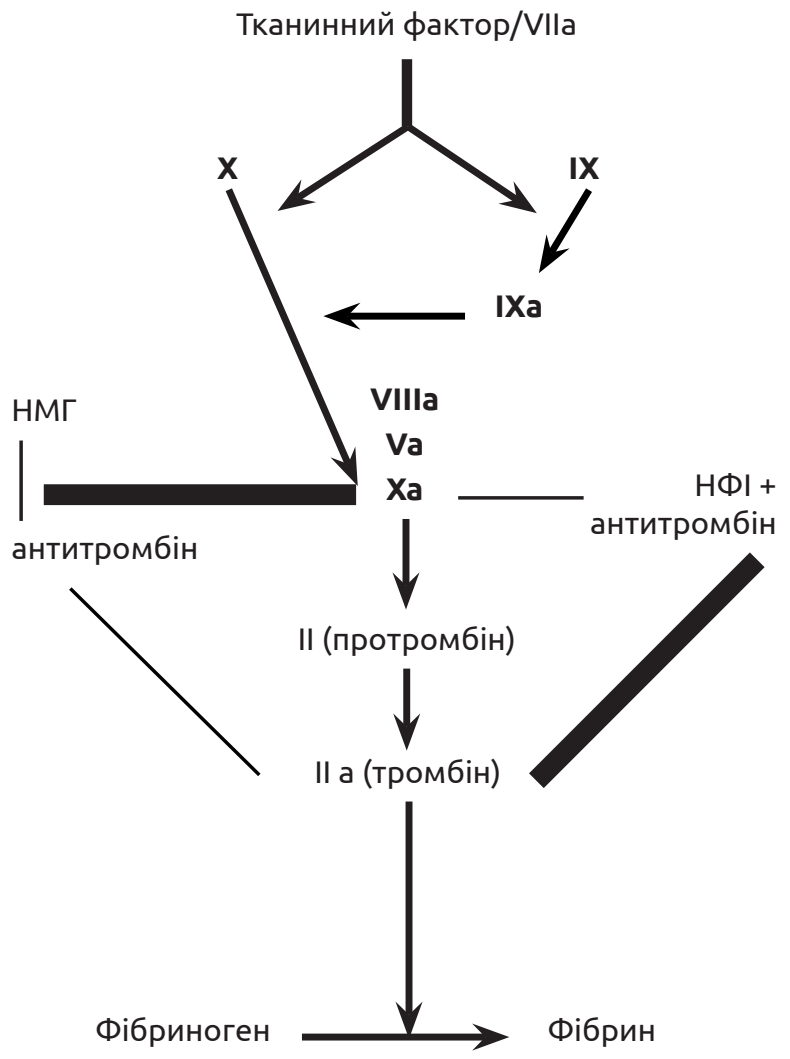

Рис. 1. Схема впливу нефракціонованого та низькомолекулярних гепаринів на коагуляційний каскад.

3 огляду на виявлену нами закономірність, 3 метою запобігання розвитку післяопераційних тромбозів у судинній системі в ранньому післяопераційному періоді, слід забезпечити надходження в організм антикоагулянта, який проявляв би домінантну дію на Ila фактор гемокоагуляційного каскаду - нефракційний гепарин (НФГ). Серед НМГ не вдалося виявити такого антикоагулянта (табл. 1).

Отже, беручи до уваги вищенаведені результати дослідження, під час проведення реконструктивних операцій у пацієнтів із атеросклеротичним ураженням магістральних артерій нижніх кінцівок за умови хронічної критичної ішемії, спосіб тром- 
Огляди літератури, оригінальні дослідження, погляд на проблему, випадок з практики, короткі повідомлення Таблиця 1. Порівняльна характеристика низькомолекулярних гепаринів

\begin{tabular}{|l|c|c|c|}
\hline \multicolumn{1}{|c|}{ Назва } & $\begin{array}{c}\text { Молекулярна маса, } \\
\text { дальтон }\end{array}$ & $\begin{array}{c}\text { Ппіввідношення } \\
\text { анти-Ха/анти-ІІа активності }\end{array}$ \\
\hline Беміпарин & 3600 & $5,2-5,4$ & 8,0 \\
\hline Надропарин & 4300 & 3,7 & $2,5-4,0$ \\
\hline Еноксапарин & 4500 & $4,0-4,4$ & $3,3-5,3$ \\
\hline Дальтепарин & 6000 & $2,3-2,8$ & $1,9-3,2$ \\
\hline
\end{tabular}

бопрофілактики має передбачати внутрішньовенне введення нефракціонованого гепарину, який проявляє домінантну дію на Ila фактор (тромбін - фібриноген) гемокоагуляційного каскаду відразу після операційного втручання.

Саме поєднання НФГ і НМГ дає можливість одночасно впливати на різні чинники згортальної системи і знизити ризик розвитку тромбозу в судинній системі.

Пацієнтам із високим ризиком розвитку реперфузійних ускладнень для тромбопрофілакти- ки слід застосовувати лікувальні дози антикоагулянтних препаратів.

Висновок. У зв'язку із збереженням гіперкоагуляційного стану згортальної системи крові впродовж першої доби, слід продовжувати призначення НФГ у дозі, половинній від початкової, протягом наступних 7-9 діб.

3 другої доби раннього післяопераційного періоду тромбопрофілактику НФГ можна замінити НМГ, які проявляють домінантну дію на Ха фактор гемокоагуляційного каскаду.

\section{ЛІТЕРАТУРА}

1. Покровский А. В. Вазапростан (простагландин Е1) в лечении тяжелых стадий артериальной недостаточности нижних конечностей : пособие для врачей / А. В. Покровский, В. М. Кошкин, А. А. Кириченко. - М., 1999. - 16 с.

2. Statin therapy in lower limb peripheral arterial disease: systematic review and meta-analysis / G. A. Antoniou, R. K. Fisher, G. S. Georgiadis [et al.] // Vascul. Pharmacol. - 2014. - Vol. 63. - P. 79-87.

3. Critical appraisal of femorofemoral crossover grafts / R. Pursell, E. Sideso, T. R. Magee, R. B. Galland // Br. J. Surg. - 2005. - Vol. 92, No. 5. - P. 129.

4. Губка В. А. Повторные реконструкции у больных облитерирующим атеросклезом с отдаленными осложнениями /В.А. Губка // Патология.-2012.-№ 2.-С. 43-45.

\section{REFERENCES}

1. Pokrovskiy, A.V., Koshkin, V.M., \& Kirichenko, A.A. (1999). Vazaprostan (prostaglandin E1) v lechenii tyazhelykh stadii arterialnoi nedostatochnosti nizhnikh konechnostey [Vazaprostan (prostaglandin E1) in the treatment of severe stages of lower limb arterial insufficiency]. Moscow [in Russian].

2. Antoniou, G.A., Fisher, R.K., Georgiadis, G.S., Antoniou, S.A., \& Torella, F. (2014). Statin therapy in lower limb peripheral arterial disease: systematic review and meta-analysis. Vascul. Pharmacol., 63, 79-87.

3. Pursell, R., Sideso, E., Magee, T.R., \& Galland, R.B. (2005). Critical appraisal of femorofemoral crossover grafts. Br. J. Surg., 92, 5, 129.

4. Gubka, V.A. (2012). Povtornye rekonstruktsii u bolnykh obliteriruyushchim aterosklezom s otdalennymi oslozhneniyami [Repeated reconstructions in patients with obliterating atherosclerosis with distant complications].

5. Вайда А. Р. Венозні тромбози після артеріальних реконструкцій / А. Р. Вайда, П. Я. Боднар // Шпитал. хірургія. - 2009. - № 2. - С. 72-74.

6. Венозний тромбоемболізм: діагностика, лікування, профілактика: Міждисциплінарні клінічні рекомендації / В.Н.Бойко, Я. С. Березницький, І. К. Венгер [та ін.] //-K., 2013. -63 с.

7. Neuregulin-1 attenuates neointimal formation following vascularinjury and inhibits the proliferation of vascular smooth muscle cells / C. M. Clement, L. K. Thomas, Y. Mou [et al.] // J. Vasc. Res. - 2007. - Vol. 44, No. 4. P. 303-312.

Patologiya - Pathology, 2, 43-45 [in Russian].

5. Vaida, A.R., \& Bodnar, P.Ya. (2009). Venozni trombozy pislia arterialnykh rekonstruktsii [Venous thrombosis after arterial reconstruction]. Shpytal. hhirurhiia - Hospital Surgery, 2, 72-74 [in Ukrainian].

6. Boiko, V.N., Bereznytskyi, Ya.S., Hryn, V.K., Нerasymenko, S.I., Hlumher, S.S., ..., \& Shchebotin, I.B. (2013). Venoznyi tromboembolizm: diahnostyka, likuvannia, profilaktyka: Mizhdystsyplinarni klinichni rekomendatsii [Venous thromboembolism: diagnosis, treatment, prevention: multidisciplinary clinical guidelines]. Kyiv [in Ukrainian].

7. Clement, C.M., Thomas, L.K., Mou, Y., Croslan, D.R., Gibbons, G.H., \& Ford, B.D. (2007). Neuregulin-1 attenuates neointimal formation following vascularinjury and inhibits the proliferation of vascular smooth muscle cells, J. Vasc. Res., 44 (4), 303-312. 
Высшее государственное учебное заведение Украины «Буковинский государственный медицинский университет»

РЕЗЮМЕ. Реконструктивные методы лечения дают возможность сохранить нижние конечности, при критической ишемии их тканей, у 45-55 \% больных. Несмотря на применение различных хирургических технологий в лечении облитерирующих заболеваний аорты и периферических артерий нижних конечностей, сегодня достаточно значительную частоту как ранних, так и поздних осложнений реконструктивных вмешательств, в частности, тромбоз сегмента реконструкции, обнаруживают в 42-59 \% наблюдений. Тромбопрофилактика с использованием отраслевых протоколов, применение алопротезов с импрегнацией ионов серебра не решают проблему.

Цель-исследование системы гемостаза при реваскуляризующих операцияху пациентов сатеросклеротическим поражением магистральных артерий нижних конечностей при хронической критической ишемии и разработка соответствующей тромбопрофилактики.

Материал и методы. Обследованы 106 пациентов, из которых у 18 больных диагностирована аневризма инфраренальной части аорты, у 39 - атеросклеротическая окклюзия аорто-подвздошного сегмента, у 13 из них сегментарная окклюзия бедренно-дистального артериального русла, у 12 - подвздошно-бедренная атеросклеротическая окклюзия, у 27 - стенотически-окклюзионное атеросклеротическое поражение бедренно-дистального артериального русла нижних конечностей. У всех пациентов при атеросклеротическом поражении артериальной системы нижних конечностей диагностирована хроническая артериальная ишемия ША - IIIB стадии (по А. В. Покровскому).

Результаты. Во время проведения реконструктивных операций у пациентов с атеросклеротическим поражением магистральных артерий нижних конечностей при хронической критической ишемии, спосо 6 тромбопрофилактики должен предусматривать введение нефракционированного гепарина, который проявляет доминантное действие на Ila фактор (тромбин - фибриноген) гемокоагуляционного каскада сразу после операционного вмешательства. Именно сочетание НФГ и НМГ дает возможность одновременно воздействовать на различные факторы свертывающей системы и снизить риск развития тромбоза в сосудистой системе. Пациентам с высоким риском развития реперфузионных осложнений с целью тромбопрофилактики следует применять лечебные дозы антикоагуляционных препаратов.

Вывод. В связи с сохранением гиперкоагуляционного состояния свертывающей системы крови в течение первых суток, следует продолжать назначения НФГ, в половинной от начальной дозы препарата, в течение следующих 7-9 суток. Со вторых суток раннего послеоперационного периода тромбопрофилактику НФГ можно заменить НМГ, которые проявляют доминантное действие на Ха фактор гемокоагуляционного каскада.

КЛЮчЕВЫЕ СЛОВА: тромбопрофилактика; хроническая критическая ишемия; реперфузионный синдром; реваскуляризация.

\section{THROMBOPROPHYLAXIS IN REVASCULARIZING OPERATIONS IN PATIENTS WITH ATHEROSCLEROTIC DEFEAT OF MAIN ARTERIES OF LOWER EXTREMITIES UNDER CONDITIONS OF CHRONIC CRITICAL ISCHEMIA}

๑O. B. Kolotylo

\section{Bukovinian State Medical University}

Introduction. Reconstructive methods of treatment make it possible to preserve the lower limbs during critical ischemia of their tissues in 45-55\% of patients. Despite the use of various surgical technologies in the treatment of obliterating diseases of the aorta and peripheral arteries of the lower extremities, today the frequency of both early and late complications of reconstructive interventions is quite significant, in particular, thrombosis of the reconstruction segment is found in $42-59 \%$ of observations. Thromboprophylaxis using industry protocols, the use of an alopecia with impregnation of silver ions do not solve the problem.

The aim of the study - to learn the hemostatic system in revascularizing operations in patients with atherosclerotic lesions of the main arteries of the lower extremities in chronic critical ischemia, and to develop appropriate thromboprophylaxis.

Material and Methods. 106 patients were examined, 18 of them were diagnosed with aneurysm of the infrarenal part of the aorta, 39 - atherosclerotic occlusion of the aorto-iliac segment, 13 of them - segmental occlusion of the femoral-distal arterial bed, 12 - iliac-femoral atherosclerotic occlusion, 27 - stenotic-occlusal atherosclerotic lesion of 
Огляди літератури, оригінальні дослідження, погляд на проблему, випадок з практики, короткі повідомлення the femoral-distal arterial bed of the lower extremities. All patients with atherosclerotic lesions of the arterial system of the lower extremities were diagnosed with chronic arterial ischemia of stage IIIA - IIIB (according to A. V. Pokrovsky).

Results and Discussion. During reconstructive operations in patients with atherosclerotic lesions of the main arteries of the lower extremities in chronic critical ischemia, the thromboprophylaxis method should include the introduction of unfractionated heparin, which exhibits a dominant effect on the second factor (thrombin - fibrinogen) of the hemocoagulation cascade immediately interventions. It is the combination of unfractionated heparin (UFH) and low molecular weight heparin (LMWH) that makes it possible to simultaneously affect various factors of the coagulation system and reduce the risk of thrombosis in the vascular system. Patients with a high risk of developing reperfusion complications with the goal of thromboprophylaxis should use therapeutic doses of anticoagulants.

Conclusion. In connection with the preservation of the hypercoagulative state of the blood coagulation system during the first day, the administration of UFH at half the initial dose of the drug should be continued for the next 7-9 days. From the second day of the early postoperative period, thromboprophylaxis of UFH can be replaced by LMWH, which exhibit a dominant effect on the Ha factor of the hemocoagulation cascade.

KEY WORDS: thromboprophylaxis; chronic critical ischemia; reperfusion syndrome; revascularization.

Отримано 24.09.2019 